\title{
PEMIKIRAN ISLAM PROGRESIF: Dua Dekade Pemikiran dan Gerakan Jaringan Islam Liberal (JIL)
}

\author{
A. Ilyas Ismail \\ Dosen pada Fakultas Ilmu Dakwah dan Ilmu Komunikasi \\ UIN Syarif Hidayatullah Jakarta \\ e-mail: ilyas_ismail@yahoo.com
}

\begin{abstract}
Theologically, Islam is one (single) and absolutely true. However, historically, after being understood, and translated into the reality of life in the dimensions of space and time, Islam is not a single, but wide in variety or has plural form and manifest in at least three schools of thought, the traditional Islamic revivalist Islam (fundamentalism), and Islam liberal (progressive). Group of the Liberal Islam Network (JIL) represents the latter mindset. Although it is relatively young, only 10 years old, JIL became popular because it brings new ideas that often arouse controversy in the community. The progressive thoughts carried out by JIL concerning the four areas. First, the reformation in politics, JIL forwards the idea of secularism. Second, in the field of social reforms and civic religion, JL brought the idea or concept of pluralism. Third, reforms in individual freedom, IIL put forward the idea of liberalism both in thought and action. Fourth, reforms in the field of women, JIL brought the idea of gender equality. These thoughts get some pros and cons in the community. Some denounce and condemn it, but others appreciate and support it. In such an atmosphere, JIL continues to grow as a progressive Islamic thought and movements in Indonesia.
\end{abstract}

\begin{abstract}
Abstrak: Secara teologis, Islam adalah satu (tunggal) dan mutlak benar. Namun, secara historis, setelah dicoba dihayati, dipahami, dan diterjemahkan dalam realitas kehidupan dalam dimensi ruang dan waktu, Islam tidak tunggal, tetapi beragam alias plural yang mewujud dan mengejawantah setidak-tidaknya dalam tiga aliran pemikiran, yaitu Islam tradisional, Islam revivalis (fundmentalisme), dan Islam liberal (progresif). Kelompok Jaringan Islam Liberal (JIL) mewakili pola pemikiran yang terakhir. Meski usianya relative muda, baru 10 tahun, JIL menjadi popular karena mengusung pemikiran-pemikiran baru yang
\end{abstract}


sering memunculkan kontroversi dalam masyarakat. Pembaharus pemikiran yang diusung IL menyangkut empat bidang. Pertama, pembaruan dalam bidang poiitik. Di sini, IL mengedepankan gagasan sekularisme. Kedua, pembaruan dalam bidang sosial agama dan kemasyarakatan. Di sini, JL mengusung ide atau konsep pluralisme. Ketiga, pembaruan dalam kebebasan individu. Dalam hal ini, IIL mengedepankan gagasan liberalism baik dalam berpikir maupun bertindak. Keempat, pembaruan dalam bidang perempuan. Di sini JIL mengusung ide kesetaraan gender. Pemikiran pembaharuan JIL ini mendapat pro dan kontra dalam masyarakat. Sebagian mencela dan mengecamnya, tetapi sebagian lagi memberi apresiasi dan mendukungnya.Dalam suasan semacam itu, JIL terus tumbuh sebagai pemikiran dan gerakan Islam progresif di Indonesia.

Keywords: Pemikiran Islam, JIL, sekularisme, pluralisme, liberalism, dan kesetaraan gender.

\section{A. Pendahuluan}

Dalam sejarah penyebarannya ke berbagai pelosok penjuru dunia, Islam telah berulang kali mengalami kontekstualisasi dengan situasi masyarakat setempat. Kontekstualisasi ini, merupakan konsekuensi logis dari doktrin Islam yang diimani sebagai agama yang relevan dengan setiap tempat dan masa (al Isläm șăliḥ li kulli zamān wa makān). Dengan demikian, Islam yang dirisalahkan pada abad VII tetap survive hingga generasi abad XXI sekarang ini. Kontekstualisasi Islam mesti dilakukan demi merespons berbagai problem yang sangat dinamis dan semakin kompleks. Respons Islam terhadap dinamika umat manusia itu menjadikan Islam sebagaimana diajarkan oleh Nabi Muhammad tidak lagi tunggal, tetapi hadir kepada generasi saat ini dengan menawarkan banyak alternatif corak pemikiran dan penafsiran.

Sejauh respons umat Islam terhadap perkembangan situasi modern, John L. Esposito membaca pola pemikiran Islam dalam empat kategori. Secara berturut-turut adalah pola pemikiran sekular, konservatif, neotradisionalis (neofundamentalis), dan reformis (neomodernis). Esposito menyebut tiga kelompok yang terakhir sebagai pola (sikap) pemikiran berorientasi agamis sebagai lawan dari yang pertama, kelompok sekular. ${ }^{1}$ 
Pertama, kelompok sekular. Menurut kelompok ini, pembaharuan Islam hanya mungkin dilakukan dengan meniru Barat secara utuh, baik sisi positif maupun negatifnya (khairihi wa sharrih). Bagi kelompok sekular, kemajuan hanya mungkin diwujudkan jika agama dibatasi hanya dalam urusan pribadi dan menjauhkannya dari kehidupan publik. Kelompok sekular percaya bahwa pencampuran agama dengan politik sejatinya hanya wujud dari manipulasi Islam untuk kepentingan politik dan bukan sebaliknya ${ }^{2}$

Kedua, kelompok konservatif, bagi kelompok yang diwakili oleh mayoritas ulama ini, pembaruan Islam hanya mungkin diwujudkan ketika umat muslim kembali menerapkan Islam secara kaffah seperti yang pernah dipraktekkan oleh pemeluknya di masa silam. Bagi mereka, kemajuan Barat diperoleh ketika agama ditinggalkan, sebaliknya Islam memperoleh kemajuannya ketika agama kembali dipraktikkan. Islam, sebagaimana pernah diartikulasikan di zaman klasik, menurut kelompok konservatif, adalah Islam yang mengatur umat muslim dan tetap sah sampai hari ini dan sepanjang zaman. ${ }^{3}$

Ketiga, kaum neotradisionalis atau neofundamentalis, yaitu kelompok pembaruan Islam yang secara umum memiliki kesamaan dengan kelompok konservatif. Bedanya, walaupun kelompok ini fanatik terhadap rumusan pemahaman Islam klasik, tetapi mereka tidak terikat dengannya. Lebih dari itu, mereka mengklaim hak untuk merujuk langsung pada sumber-sumber Islam utama (al-Qur'ān dan al-Sunnah) dan mengkampanyekan ijtihad. Menurut Esposito, gerakan-gerakan yang aktif dalam aksi politik semisal al-Ikhwān al-Muslimūn dan Jamaat-i-Islami adalah mewakili pandangan kelompok neofundamentalis ini. ${ }^{4}$

Keempat, kelompok neomodernis (reformis), yaitu kelompok pembaruan Islam yang menilai perlunya membuat jarak antara substansi agama (Islam) dan pemahaman agama (muslim). Seperti halnya kelompok neotradisonalis, kelompok neomodernis juga meyakini bahwa periode Islam awal adalah periode yang mewujudkan idealitas Islam. Bedanya, kelompok ini memberi penegasan bahwa relevansi idealitas itu hanya terbatas untuk masanya. Karena itu, umat Islam sekarang perlu membangun pandangan baru bagi masyarakat ideal sesuai dengan 
semangat situasi kontemporer. Bagi mereka, pemahaman Islam yang kita warisi sekarang adalah pemahaman Islam yang tidak lepas dari konteks perjalanan historis. Untuk itu, pembaruan Islam hanya mungkin diwujudkan ketika pemahaman Islam tersebut didekonstruksi untuk kemudian direkontuksi ulang dengan perangkat-perangkat kekinian. ${ }^{5}$

Dalam analisis Esposito, kelompok neotradisionalis (fundamentalis) memiliki kesamaan dengan kelompok neomodernis dalam aspek mengkampanyekan ijtihad dan klaim untuk kembali merujuk sumber utama Islam. Walaupun demikian, tampaknya ijtihad yang dikampanyekan oleh kaum fundamentalis dilakukan dengan separuh hati. Sehingga alih-alih melakukan pembacaan baru terhadap Islam, yang ada kelompok fundamentalis ini terjebak ke dalam kebekuan dan kekakuan penafsiran sebagaimana kaum tradisionalis. Karena itu, baik kelompok tradisionalis maupun fundamentalis, bisa dikelompokkan ke dalam kategori Islam konservatif, yaitu kelompok Islam yang berusaha menjadikan masa lalu sebagai model untuk saat ini. ${ }^{6}$

Pada akhirnya, mereka yang mampu beradaptasi dengan kondisi mutakhir dan melakukan ijtihad dalam pengertian yang sebenarnya adalah kelompok neomodernis. Walaupun mereka berangkat dari tradisi, namun pembacaan mereka atas tradisi Islam itu jauh lebih progresif dan liberal dibandingkan kelompok Islam konservatif. ${ }^{7}$ Berbeda dengan kaum konservatif, penafsiran progresif dari kelompok neomodernis itu amat radikal hingga mempertanyakan ulang produk-produk penafsiran tradisional Islam. Dengan pendekatan penafsiran yang liberal-progresif itu, maka kelompok neomodernis Islam biasa dikenal dengan kelompok muslim liberal, atau muslim progresif. ${ }^{8}$ Saat ini, di Indonesia terdapat fenomena persaingan antara dua kubu yang masing-masing memperebutkan pengaruhnya di ruang publik, Islam progresif dan Islam konservatif.

Seperti halnya terlihat pada negeri-negeri Muslim di seluruh dunia, persaingan untuk memperebutkan pengaruh di ruang publik antara penafsiran Islam konservatif dan progresif juga terlihat di Indonesia. Berbeda dengan masa pemerintahan Soeharto, Indonesia paska reformasi tahun 1998 memberikan ruang kebebasan berekspresi bagi kaum 
muslimin. Pada awal tahun 2001, tokoh-tokoh muslim progresif di Indonesia membentuk suatu jaringan yang bertujuan menaungi dan mengikat pelbagai gerakan dan pemikiran bercorak liberal-progresif di dalam negeri. ${ }^{9}$ Pada awal mulanya, gerakan yang kemudian disebut Jaringan Islam Liberal (JIL) ini muncul sebagai respon atas munculnya Islam orotodok atau konservatif yang mulai mendominasi ruang publik di Indonesia pada era-era tersebut. Dengan sokongan dari 28 kontributor domestik dan Internasional, tokoh-tokoh muda seperti Luthfi Assaukanie (Paramadina), Ulil Abshar Abdalla (Lakpesdam NU) dan Ahmad Sahal (jurnal Kalam) disebut-sebut terlibat sebagai pengelola periode awal JIL. ${ }^{10}$

Saat ini, periode di mana memasuki usianya yang kesepuluh, JIL dengan program-programnya telah banyak mewarnai pemahaman penafsiran Islam Indonesia modern. Tentu saja perjuangan itu bukannya tanpa hambatan dan perlawanan. Seperti telah dijelaskan di muka, JIL sebagai corong penafsiran Islam bercorak progresif dihadapkan dengan perlawanan sejumlah organisasi, ormas baik dari kelompok muslim radikal-fundamental maupun tokoh-tokoh ulama konservatif-ortodoks. Singkat kata, kemunculan JIL dalam kancah pemikiran Islam di Indonesia telah menjadi semacam kontroversi publik. Seperti halnya perlawanan dari kelompok fundamental dan konservatif tersebut, dukungan moral dan material terhadap gerakan ini juga berdatangan dari banyak pihak, baik dalam maupun luar. Dalam perkembangan berikutnya, eksistensi JIL di Indonesia menjadi suatu fenomena yang menarik untuk diteliti oleh banyak kalangan, baik dari dalam maupun internasional.

Tidak kurang sejumlah artikel dan disertasi ditulis sebagai bentuk analisis atas gerakan Islam progresif ini. Sebut saja artikel bertema "The Rise of Liberal Islam Network in Indonesia" yang ditulis oleh Muhammad Ali, seorang dosen UIN Syarif Hidayatullah Jakarta yang menjalani studi doktoralnya di Universitas Hawaii Amerika Serikat. Artikel setebal 26 halaman ini membahas tentang fenomena kebangkitan Islam liberal di Indonesia dengan spesifikasi bahasan JIL. Ada lagi tulisan bertajuk "Developing Islamic Argument for Change Through Liberal Islam" yang disusun oleh Virginia M. Hooker, guru besar studi asia di Australian National University (ANU). Tulisan 
setebal tidak kurang dari 29 halaman ini merupakan kumpulan tulisan dari jurnal studi Asia Tenggara yang digarapnya bersama Amin Saikal. Dari disertasi, ada tulisan dari Nicolaus Teguh Budi Harjanto bertajuk "Islam and Liberalism in Contemporary Indonesid" yang ditujukan kepada fakultas Arts dan Sciences di Universitas Ohio. Nah, penelitian sederhana ini, lebih jauh bermaksud melaporkan pengamatan atas perkembangan 10 tahun pemikiran dan gerakan JIL di Indonesia (Maret 2001-2011), terkait sejarah kelahiran, gagasan-gagasan, gerakan dan sosialisasi ide, respon dan analisa atau prediksi masa depannya. Penelitian fenomonologi ini dilakukan atas metode kualitatif dengan studi kepustakaan dan dilengkapi dengan wawancara.

\section{B. Historis Kelahiran Jaringan Islam Liberal di Indonesia}

Sebagaimana disinggung di atas, ada keterkaitan antara era reformasi di Indonesia (1997-1998) dengan kebangkitan pemikiran dan gerakan Islam liberal. Sebelum reformasi, pemerintahan rezim Soeharto berusaha menekan sebisa mungkin aspirasi-aspirasi kelompok Islamis dan mencegahnya tampil terbuka di ruang publik. Ketika pemerintahan Soeharto berakhir, ruang politik mulai terbuka dan lebih demokratis. Bersama dengan itu, orang-orang radikal-fundamentalis dan kelompok Islamis yang dulu pernah dibungkam di masa Soeharto, kini mulai memberanikan diri muncul ke permukaan. ${ }^{11}$

Fakta menunjukkan bahwa di era pemerintahan baru Indonesia, kelompok radikal-fundamentalis itu lebih vokal mengkampanyekan ideidenya. Bagi kebanyakan kelompok muslim moderat, fenomena ini menjadi suatu yang mengkawatirkan bagi kelangsungan Indonesia di masa depan. Kekhawatiran itu terutama dibuktikan bersamaan dengan munculnya konflik antar etnis-agama di beberapa wilayah lokal seperti Kalimantan dan Sulawesi. ${ }^{12}$ Kelahiran kelompok-kelompok seperti Majelis Mujahidin Indonesia (MMI), Front Pembela Islam (FPI), Partai Keadilan (PK), Hizbut Tahrir Indonesia (HTI) serta kelompokkelompok fundamentalis lainnya yang ditengarai menjadi sebab munculnya konflik antaragama dipandang makin mengancam kesatuan NKRI.. ${ }^{13}$ 
Kelompok muslim moderat memandang situasi seperti tersebut di atas makin tidak bisa dibiarkan. Sebab jika tidak, lama kelamaan situasi tersebut akan menggerogoti wibawa negara dan merusak demokratisasi dan toleransi di Indonesia. ${ }^{14}$ Mereka melihat, bahwa semakin hari kelompok muslim radikal-fundamental makin militan, sistematis, dan terorganisisasi. Sementara itu, pemikiran dan kelompok muslim moderatprogresif lemah, tidak terorganisisasi, tidak mempunyai perlawanan, apalagi kekuatan untuk menyampaikan ide-ide pembaruannya. ${ }^{15}$ Untuk itulah, pada awal tahun 2001 enam pemuda muslim progresif-Ulil Abshar Abdalla, Luthfi Assaukanie, Hamid Basyaib, Ihsan Ali Fauzi, Nong Darol Mahmada dan Ahmad Sahal-berkumpul dan membicarakan pentingnya membangun suatu jaringan gerakan pemikiran progresif di Indonesia. Kemudian pada tanggal 8 Maret 2001, berdirilah sebuah jaringan yang memayungi pemikiran-pemikiran liberal di Indonesia yang kemudian dikenal orang dengan Jaringan Islam Liberal (JL). ${ }^{16}$

Pendirian JIL yang diprakarsai dan difasilitasi oleh budayawan Goenawan Muhammad itu ditandai dengan diadakannya diskusi perdana di Teater Utan Kayu Jakarta dan peluncuran mailing list JIL dan selanjutnya website www.Islamlib.com. Ketika didirikan, JIL tidak diniatkan sebgai sebuah organisasi formal seperti halnya Muhammadiyah atau Nahdlatul Ulama (NU). Menurut para pendirinya, JIL hanyalah organisasi jaringan saja, yang bersifat cair dan lepas. Pendirian tersebut kemudian diikuti oleh perlawanan depensif dari kelompok-kelompok fundamentalis yang merasa tertandingi dan terancam eksistensinya di Indonesia. ${ }^{17}$

\section{Gagasan Pembaruan Kelompok Muslim Progresif}

Sebagai bentuk respon terhadap situasi modern, pemikiran progresif Islam sejatinya adalah suatu bentuk usulan pembaharuan agama. Agar Islam bisa relevan dengan konteks kehidupan umat manusia mutakhir, ia harus ditafsirkan ulang. Dalam pandangan muslim progresif, penafsiran ulang atas Islam tidak didasarkan atas model masa lalu, seperti pandangan kaum fundamentalis, tetapi didasarkan atas kondisi kekinian dan temuan-temuan terbaru ilmu pengetahuan. Tradisi dan

TEOLOGIA, VOLUME 23, NOMOR 2, JULI-DESEMBER 2012 
masa lalu, mesti dipahami semangatnya secara konstektual sesuai kebutuhan zaman saat itu. Dalam pemikiran progresif Islam, semangat substansial dari masa lalu itulah yang ditransfer ke masa kini, dan bukan model formalnya. ${ }^{18}$

Untuk menafsirkan Islam sesuai dengan konteks kekinian itu, kelompok muslim progresif dari JIL mengajukan ide pembaharuan dalam empat ranah kehidupan masyarakat Islam. Pertama, pembaruan dalam aspek kehidupan bernegara melalui konsep sekularisme. Kedua, pembaruan dalam aspek kehidupan sosial-kemasyarakatan melalui konsep pluralisme. Ketiga, pembaruan dalam aspek kehidupan individu melalui konsep liberalisme. Keempat, pembaruan dalam bidang kesetaraan gender. Walaupun bidang garapannya berbeda, keempat agenda pembaharuan Islam progresif itu berkait-kelindan satu sama lain.

Sekularisasi yang dimaksud para pemikir progresif adalah desakralisasi dan demitologisasi. Baik desakralisasi maupun demitologisasi, masing-masing mengarah kepada diferensiasi, pembedaan antara yang sakral dan yang profan, dan bukan memisahkan antara persoalan duniawi dan ukhrawi. ${ }^{19}$ Dalam konteks kehidupan bernegara, diferensiasi ini amat penting agar negara tidak mempolitisasi agama pada satu sisi, dan agar agama tidak menjadi beban negara di sisi yang lain. Dalam pandangan muslim progresif, negara yang sehat adalah bentuk negara demokratis. Negara yang berpaham demokrasi dalam pengertian yang sebenarnya, menurut pemikir muslim progresif, tidak bisa kecuali didirikan di atas landasan sekularisme. ${ }^{20}$ Luthfi Assaukanie, misalnya, menyebut tiga usulan model negara demokrasi di Indonesia, negara Islam demokrasi, negara religius demokrasi, dan negara sekular demokrasi. Menurut Assaukanie, dua model yang pertama adalah bentuk negara demokrasi yang semu, atau demokrasi setengah hati. Sebaliknya, negara yang mampu menjalankan demokrasi dengan benar adalah negara dalam bentuknya yang sekular. ${ }^{21}$

Dalam negara yang sekular, agama disikapi secara netral. Negara tetap menghormati orang beragama, tapi di sisi lain tidak menganakemaskan bentuk agama tertentu. Agama-agama itu dalam konteks negara sekular adalah sederajat dan memiliki ruangnya tersendiri. Dalam hal ini, negara hanya boleh menjalankan aspirasi yang menampung se- 
mua kepentingan warga negara. Adalah sebuah kesalahan beranggapan bahwa negara sekular mengancam eksistensi agama dan umat beragama. Justru menurut para pemikir progresif, model negara sekular adalah upaya untuk melindungi kebebasan beragama dan menyelamatkan agama-agama. Kenyataannya, begitu pemikir muslim progresif berargumen, dalam praktik negara-negara maju yang berpaham sekular, agama-agama tetap hidup dan dihormati keberadaannya. ${ }^{22}$

Bagi para pemikir muslim progresif, sekularisme adalah konsekuensi logis dari demokrasi. Demokrasi sendiri, sejatinya kelanjutan dari penerimaan konsep nation-state yang menggantikan bentuk lama negara teokrasi. Sejak pembaruan Islam digulirkan, umat muslim kebanyakan sudah bisa menerima demokrasi dan bentuk negara bangsa, tapi mereka masih kesulitan untuk menerima sekularisme. Padahal, demokrasi yang benar sejatinya tidak mungkin dijalankan tanpa sekularisme. Negara yang hanya mau menjalankan demokrasi, tanpa menerima sekularisme, dalam praktiknya nanti justru akan mencedari prinsip-prinsip demokrasi itu sendiri, ${ }^{23}$ Dari sini, para pemikir muslim progresif hendak mengatakan, jika negara-negara muslim ingin mengejar ketertinggalannya mereka mesti memperbarui pandangan keagamaan mereka dan mulai belajar menerima sekularisme.

Dari segi pembaruan kehidupan sosial, para pemikir progresif JIL mengusulkan ide pluralisme. Jika sekularisme berusaha menempatkan agama-agama secara proporsional dengan menghindari politisasi negara terhadap agama, maka pluralisme berusaha memperbaharui pandangan eksklusif dalam doktrin agama-agama. Menurut para pemikir muslim progresif, doktrin tentang superioritas suatu agama yang mengatasi agama-agama lain dalam konteks masyarakat yang plural tidak mungkin lagi dipertahankan. Lebih dari itu, para umat beragama itu dituntut untuk terlibat aktif, bekerja sama dalam penuntasan masalah-masalah kemanusiaan. Keaktifan dan kerja sama tersebut mengharuskan adanya dialog teologis antar keyakinan (interfaith dialouge). ${ }^{24}$

Ide pluralisme memang menafikan pandangan tentang satu-satunya agama yang paling benar, tapi juga sebuah kesalahan memandang pluralisme sebagai paham yang menyamakan semua agama. Pluralisme 
memandang tiap-tiap agama sebagai yang unik, dan benar menurut kriteria masing-masing (it's valid within it's categories) ${ }^{25}$ Dalam pemikiran muslim progresif, paham pluralisme menolak menggunakan standar ganda untuk menilai agama orang lain. Lebih dari itu, paham pluralisme mengajak untuk memandang penganut agama lain sebagai rekan seperjalanan (fellow traveler), dan bukan sebagai pihak lian. ${ }^{26}$

Menurut Budy Munawar Rachman-salah seorang pemikir muslim progresif Indonesia-pluralisme mencakup tiga pengertian. Pertama, pluralisme menghendaki adanya keterlibatan aktif dalam perbedaan dan keragaman untuk membangun peradaban bersama. Pluralisme, demikan Rachman, menghendaki lebih dari sekedar mengakui pluralitas keragaman dan perbadaan, tetapi mengajak untuk aktif merangkai keragaman dan perbedaan itu untuk tujuan sosial yang lebih tinggi, yaitu kebersamaan dalam membangun peradaban. Kedua, pluralisme bukan hanya sekedar toleransi. Menurut Rachman, pluralisme mengandaikan pengenalan secara lebih mendalam atas yang lain itu hingga melahirkan mutual understanding. Dalam konteks pembaruan aspek kehidupan sosial, bentuk mutual understanding itu amat diperlukan demi melahirkan transformasi keragaman kepada toleransi konstruktif yang bisa menjadi landasan menciptakan sebuah peradaban seperti pernah terjadi dalam sejarah Spanyol Islam (Andulusia). Ketiga, pluralisme bukan relativisme. Pengalaman mendalam atas yang lain, begitu Rachman menjelaskan, akan membawa konsekuensi mengakui sepenuhnya nilai-nilai dari kelompok yang lain. Walaupun demikian, toleransi yang aktif tersebut menolak paham relativisme, seperti pernyataan simplistis bahwa "semua agama itu sama saja". Sebaliknya, yang diinginkan dari pluralisme adalah mengelola potensi keragaman itu untuk membangun komitmen bersama mewujudkan toleransi aktif, sebagai dasar konstruksi sebuah peradaban. $^{27}$

Untuk memperbarui pemahaman keagamaan ke arah pluralisme, kaum muslim progresif berusaha mengajukan konsep common platform agama-agama. Jadi, walaupun secara formal agama-agama itu verlainan satu sama lain, tetapi secara esensial semuanya memiliki cita-cita dan tujuan yang sama. Dalam masyarakat plural seperti Indonesia ini, begitu 
kaum muslim progessif, yang perlu ditonjolkan adalah kesamaan esensial agama-agama itu, dan bukan aspek formalnya. ${ }^{28}$ Dalam konteks sipil, teologi pluralisme ini kemudian dielaborasi lebih jauh menjadi multikulturalisme, suatu paham kebernegaraan yang menempatkan agamaagama dalam ranah kultur yang beraneka ragam. Negara memposisikan semua religio-culture itu dalam kedudukan yang setara dan menampung semua aspirasi secara proporsional dan seimbang. Menurut pandangan kaum muslim progresif, ide multikulturalisme sebagai kelanjutan pluralisme ini diusulkan, untuk melahirkan suatu format negara welfare state seperti negara-negara maju pada umumnya. ${ }^{29}$

Adapun ide liberalisme, diusulkan sebagai bentuk pembaruan dalam aspek individu. Liberalisme yang dimaksudkan para pemikir muslim progresif adalah kebebasan dalam tiga aspek. Pertama, kebebasan berkeyakinan. Kedua, kebebasan berpikir dan menafsirkan agama. Ketiga, kebebasan hak-hak sipil. ${ }^{30}$ Liberalisme dalam pandangan muslim progresif, tidak identik dengan kebebasan yang tanpa batas. Istilah "jangan kebablasan" dalam mencari kebebasan menjadi tidak relevan. Demikian itu, karena setiap kebebasan pada hakekatnya akan dibatasi oleh kebebasan orang lain juga. Dengan demikian, liberalisme itu tidak menghendaki anarkis dan justru berdiri di atas dan menghormati hukum. ${ }^{31}$

Dalam pandangan kelompok muslim progresif, berkeyakinan atau menjadi beragama adalah suatu yang amat dihormati. Ia tidak dipaksakan kepada seseorang dengan alasan apapun. Manusia, begitu muslim progresif, dilahirkan dengan kebebasan memilih beragama atau tidak beragama, atau memilih memeluk suatu agama tertentu. Agama mesti diyakini dan dijalankan dengan ketulusan dan keikhlasan. Keyakinan agama yang dipaksakan, justru akan melahirkan kepura-puraan (hipocricy) dalam beragama. Keberagamaan yang demikian tentu bukanlah sikap yang dikehendaki oleh semua agama-agama. ${ }^{32}$ Termasuk dalam konsep kebebasan beragama, adalah memberikan ruang bagi kemunculan aliran agama tertentu, dan juga kemunculan agama baru. Fenomena demikian itu, seharusnya tidak menjadi kekhawatiran apalagi

TEOLOGIA, VOLUME 23, NOMOR 2, JULI-DESEMBER 2012 
ancaman bagi agama-agama otoritas, tetapi justru menjadi tantangan untuk membuktikan peranannya diruang publik. ${ }^{33}$

Kekerasan atas nama agama terhadap jemaat Ahmadiah dan pengrusakan tempat-tempat ibadah yang terjadi belakangan ini, menurut pemikir muslim progresif, adalah bukti kegagalan agamaagama menerapkan prinsip kebebasan beragama dan berkeyakinan di Indonesia. $^{34}$ Karena itulah, maka kebutuhan akan liberalisme di Indonesia menjadi suatu yang tidak bisa dihindari. Aplikasi paham liberalisme, oleh negara dilakukan dengan menciptakan kondisi yang kondusif untuk sistem demokrasi. Prinsip tersebut diwujudkan ke dalam suatu undang-undang yang mendukung dan memayungi kebebasan beragama dan berkeyakinan. Undang-undang tersebut, demikian kelompok progresif menjelaskan, diperlukan untuk memproteksi warga dari tindakan diskriminasi, eksploitasi dan kekerasan yang mengatasnamakan agama di satu sisi, sekaligus membatasi otoritas negara supaya tidak mencampuri keyakinan, ibadah, dan aturan-aturan agama pada sisi yang lain. $^{35}$

Selain kebebasan berkeyakinan dan memilih agama, liberalisme juga menghendaki kebebasan individu untuk berfikir dan menafsirkan sendiri agamanya. Menurut para pemikir muslim progresif, Islam tidak memberikan keistimewaan kepada kelompok tertentu untuk menafsirkan agama (lā ruḥbāniyyata fi al-islām). Lebih dari itu, masingmasing individu dipersilahkan untuk mendalami dan memahami agamanya sesuai dengan taraf kemampuannya. Karena itu, para pemikir muslim progresif menolak setiap bentuk otoritas penafsiran pemuka agama. Liberalisme menghendaki agar dominasi tokoh-tokoh keagamaan dihilangkan dan dipersempit ruangnya untuk mereka tampil secara lebih besar. Demikian itu diupayakan agar tidak ada lagi kekhawatiran individu dari segala bentuk intimidasi yang mengatasnamakan agama seperti pemurtadan, penyesatan atau pengkafiran. ${ }^{36}$

Menurut para pemikir muslim progresif, sejarah kemajuan Islam adalah sejarah kebangkitan liberalisme. Pada masa keemasan Islam, kebebasan berpikir dihargai dan tidak pernah dicurigai. Karena itu, menurut catatan Muhammad Iqbal-sarjana kenamaan India - saat itu tidak 
heran jika sejarah menyebut tidak kurang dari seratus sistem teologi muncul dalam Islam. ${ }^{37}$ Liberalisme dalam sejarah pemikiran Islam telah menghasilkan kreativitas dan kemajuan-kemajuan yang signifikan di masanya. Situasi demikian itu, terutama didukung oleh sikap para khalifah yang menghargai kebebasan berpikir dan berpendapat. Kemunduran Islam justru terjadi, ketika dominasi otoritas mulai menggantikan kebebasan berfikir dan kejumudan menggantikan kedinamisan. Untuk itu, pemikir progresif mengajak kepada kebebasan berfikir dengan membuka ruang ijtihad seluas-luasnya dalam seluruh aspek kehidupan dan menghidupkan kembali tradisi liberalisme Islam tersebut. ${ }^{38}$

Liberalisme juga bergerak dalam pembelaan hak-hak sipil dan minoritas. Suatu negara adalah demokratis, diukur dari sejauh mana hak-hak sipil dan minoritas itu dihormati di dalamnya. Negara demokratis dalam pengertian yang sebenarnya menghargai aspirasi tiap individu dan kelompok minoritas. Islam dalam pandangan pemikir progresif, diperuntukkan bukan hanya menaungi umatnya, tapi untuk seluruh kelompok dan golongan. Kejayaan Islam terjadi, bilamana setiap kelompok termasuk minoritas merasa ternaungi dan dihargai aspirasi dan keberadaannya. Prinsip liberalisme juga memberikan kebebasan kepada setiap individu untuk menentukan sendiri bagaimana ia hidup dan melakukan apa yang diinginkan dengan penuh tanggung jawab. Hal demikian dalam pandangan pemikir progresif tidak perlu dikuatirkan secara berlebihan, toh pada akhirnya kebebasan individu juga dibatasi oleh kebebasan orang lain. ${ }^{39}$

Untuk melindungi hak-hak sipil dan minoritas itu, maka sistem liberalisme disertai dengan penegakan hukum (rule of law). Karena kebebasan itu tidak mungkin terjadi tanpa adanya aturan-aturan hukum. Liberalisme hendak mendukung pemerintahan demokratis yang menjunjung tinggi asas kedaulatan rakyat sebagai ganti pemerintahan teokratis yang berdasarkan atas keyakinan agama, atau pemerintahan otoriter yang mengekang hak-hak sipil warganegara. Dalam sistem liberal, kelompok kepercayaan, agama, atau aliran keagamaan minoritas dilindungi selama tidak melakukan pemaksaan dan mengganggu ketertiban umum. Begitupun negara berkewajiban melindungi kelompok mi-

TEOLOGIA, VOLUME 23, NOMOR 2, JULI-DESEMBER 2012 
noritas yang tergolong sub budaya (sub culture) seperti kelompok LGBT (lesbian, gay, biseksual dan transgender).

Dalam praktiknya, negara-negara maju yang menerapkan liberalisme justru kebebasan lebih terjamin. Setiap individu dilindungi haknya untuk mengeluarkan pendapat secara bebas tanpa perlu takut ditangkap dan dimasukkan penjara. Liberalisme menjadi semacam alat yang ampuh untuk melakukan kritik diri dalam konteks bernegara. Sebab, dengan sistem liberalisme setiap warganegara menjadi terbebas dari tekanantekanan sistem yang ada. Karena itu, jika Indonesia dan negara muslim ingin mengejar ketertinggalannya, menurut para pemikir muslim progresif, sudah saatnya sekarang tidak perlu lagi takut untuk menerapkan prinsip liberalisme tersebut.

Dalam persoalan gender, pemikir muslim progresif mengusulkan ide kesetaraan dan menghapus pandangan keagamaan yang bias gender. Dalam pandangan muslim progresif, penafsiran patriarkhis dalam Islam adalah produk sejarah dan bukan berasal dari Islam itu sendiri. Sejatinya ajaran Islam, begitu pemikir muslim progresif menjelaskan, memihak kepada perempuan. Karena itu, doktrin-doktrin keagamaan klasik yang mendeskriditkan posisi perempuan mesti ditafsir ulang. Penafsiran ulang atas posisi perempuan harus mencakup semua aspek kehidupan, dari mulai partisipasi perempuan di ruang publik, wilayah pernikahan, waris, kehidupan sosial, hingga wilayah ritual atau ibadah. ${ }^{40}$

Bagi para pemikir muslim progresif, kesempatan perempuan untuk berpartisipasi dan membentuk opini di ruang publik adalah sama luasnya dengan laki-laki. Islam dalam pandangan mereka, mengizinkan kaum perempuan untuk menjadi pemimpin, dan bahkan menjadi kepala negara sekalipun. Walaupun pandangan umat muslim belakangan terhadap perempuan boleh dibilang sedikit mulai bergerak maju, ${ }^{41}$ dalam pandangan pemikir muslim progresif, saat ini perjuangan untuk membebaskan perempuan dari dominasi laki-laki belum selesai. Demikian itu, karena pembatasan gerak perempuan di ruang publik sejauh ini masih berlangsung. Fenomena tersebut masih terlihat di dunia muslimseperti Afghanistan, Pakistan, Sudan atau Arab Saudi-terutama dalam 
pembatasan fungsi Masjid yang tadinya merupakan ruang publik menjadi milik laki-laki. ${ }^{42}$

Pembaruan penafsiran terhadap perempuan juga dilakukan dalam bidang pernikahan. Untuk saat ini, mungkin pandangan tentang anjuran dasar perkawinan adalah monogami sudah bisa diterima oleh banyak kalangan umat muslim. Namun demikian, para muslim progresif melangkah lebih jauh ketika berbicara persoalan perwalian dan pernikahan dua orang dengan keyakinan yang berbeda. Pemikir muslim progresif menilai sistem perwalian bagi perempuan adalah penafsiran yang bias gender, sebagaimana larangan nikah beda agama sebagai penafsiran yang ekslusif. Menurut para pemikir muslim progresif, wanita memiliki hak sepenuhnya atas dirinya, dan karena itu pernikahan tidaklah membutuhkan wali. Begitupun dalam soal pernikahan, tidaklah disyaratkan harus se-iman. Demikian itu adalah pilihan yang terkait dengan konteks masing-masing personal. Pernikahan lelaki muslim dengan wanita muslim, atau wanita muslimah dengan lelaki non muslim adalah sah-sah saja menurut agama. ${ }^{43}$

Dalam persoalan waris, penafsiran literal yang mereduksi jatah perempuan juga ditafsir ulang. Menurut para pemikir progresif, umat muslim secara teologis masih terikat oleh penafsiran klasik yang mengatakan perempuan mendapat separuh jatah laki-laki walaupun secara praktik doktrin ini mulai ditinggalkan masyarakat. ${ }^{44}$ Dalam bidang sosial, para pemikir muslim progresif menolak doktrin jilbabisasi perempuan. Dalam pandangan pemikir muslim progresif, jilbab adalah budaya arab, dan bukan syari'at Islam itu sendiri. Karena itu, berjilbab bagi muslimah adalah soal pilihan, dan bukan imperial. ${ }^{45}$ Dalam bidang ibadah, para pemikir progresif menolak pandangan klasik tentang keharaman wanita menjadi imam laki-laki. Menurut mereka, wanita itu sah menjadi imam salat, bukan hanya untuk sesama wanita dan anakanak, tetapi pula bagi kaum laki-laki. ${ }^{46}$ 


\section{Bentuk Gerakan dan Sosialisasi Ide Jaringan Islam Liberal}

Bagi banyak orang, ide-ide atau gagasan pemikiran muslim progresif atau mereka yang tergabung dalam jaringan Islam Liberal (JIL) memang tidak mudah untuk dicerna. Karena itu, dalam satu dasawarsa belakangan ini, JIL pernah beberapa kali mengganti strategi sosialisasi ide-idenya. Pada awal-awal periode pergerakan JIL, setidaknya ada tujuh program yang dijalankan untukmensosialisasikan gagasan JIL.

Pertama, sindikasi penulis Islam liberal. Maksudnya adalah mengumpulkan tulisan sejumlah penulis yang selama ini dikenal (atau belum dikenal) oleh publik luas sebagai pembela pluralisme dan inklusivisme. Sindikasi ini akan menyediakan bahan-bahan tulisan, wawancara dan artikel yang baik untuk koran-koran di daerah yang biasanya mengalami kesulitan untuk mendapatkan penulis yang baik. Dengan adanya "otonomi daerah", maka peran media lokal makin penting, dan suara-suara keagamaan yang toleran juga penting untuk disebarkan melalui media daerah ini. Setiap minggu, akan disediakan artikel dan wawancara untuk koran-koran daerah. ${ }^{47}$

Kedua, mengadakan talk-show tentang pelbagai isu sosialkeagamaan di tanah air. Perbincangan ini diudarakan melalui radio-radio chanel Islam liberal di seluruh penjuru nusantara semisal Radio Namlapanha di Jakarta, Radio Smart di Menado, Radio DMS di Maluku, Radio Unisi di Jogja, Radio PTPN di Solo, Radio Mara di Bandung, sampai Radio Prima FM di Aceh. ${ }^{48}$

Ketiga, Penerbitan Buku. JIL berupaya menghadirkan buku-buku yang bertemakan pluralisme dan inklusivisme agama, baik berupa terjemahan, kumpulan tulisan, maupun penerbitan ulang buku-buku lama yang masih relevan dengan tema-tema tersebut. Saat ini JIL sudah menerbitkan buku kumpulan artikel, wawancara, dan diskusi yang diselenggarakan oleh JIL, berjudul Wajah Liberal Islam di Indonesia. ${ }^{49}$

Keempat, penerbitan buku-buku saku. Untuk kebutuhan pembaca umum, JIL menerbitkan Buku saku setebal 50-100 halaman dengan bahasa renyah dan mudah dicerna. Buku Saku ini akan mengulas dan menanggapi sejumlah isu yang menajdi bahan perdebatan dalam masya- 
rakat. Tentu, tanggapan ini dari perspektif Islam Liberal. Tema-tema itu antara lain: jihad, penerapan syariat Islam, jilbab, penerapan ajaran "memerintahkan yang baik, dan mencegah yang jahat" (amr ma'ruf, nahy munkar), dan lain-lain. ${ }^{50}$

Kelima, melalui mailinglist Islam liberal dengan alamat: islamliberalyahoogroups.com. Keenam, iklan layanan masyarakat yang berisi tema-tema seperti pluralisme, penghargaan atas perbedaan, dan pencegahan konflik sosial. ${ }^{51}$ Sebuah Iklan berjudul "Islam warna-warni" yang pernah ditayangkan di dua stasiun televisi swasta di Indonesia. ${ }^{52}$ Ketujuh, diskusi-diskusi keislaman yang diselenggarakan atas kerjasama antar organisasi liberal dan diskusi keliling yang dipelopori oleh para mahasiswa di tanah air. ${ }^{53}$ Termasuk dalam diskusi ini adalah workshop dan diskusi terbatas di bulan Ramadan yang diadakan setahun sekali sejak tahun $2001 .^{54}$

Seperti layaknya organisasi lain, JIL juga melakukan penyesuaian agenda dan beberapa programnya sesuai dengan situasi dan perkembangan yang terjadi. Dalam tahun 2002 misalnya, iklan layanan masyarakat tentang "Islam warna-warni" diberhentikan sepihak oleh statisun televisi yang menayangkannya karena adanya intimidasi dari kelompok ekstrimis yang memusuhi agenda-agenda pembaruan di Indonesia. ${ }^{55}$ Mengenai penghentian sepihak iklan layanan masyarakat ini, Luthfi Assaukanie, salah seorang koordinator JIL menyayangkan dan menilainya sebagai suatu tindakan yang menghembuskan iklim penindasan berekspresi. Bagi Assaukanie, iklan tersebut memiliki pesan yang amat relevan dengan perkembangan situasi pemikiran Islam kontemporer di Indonesia yang amat beragam. Katanya,

Frase "Islam Warna-Warni" adalah pilihan akhir yang keluar dari kesadaran penuh dan bukan dari kenendak main-main yang tidak punya dasar sama sekali. Pesan yang ingin disampaikan dari iklan tersebut adalah bahwa Islam adalah agama yang beragam ketika ia dipraktikan oleh kaum muslim. Secara gamblang, pesan itu mengjak umat Islam menolak pemahaman satu Islam, karena pemahaman seperti ini dapat menjurus kepada pembenaran kelompok tertentu dan menafikan kelompok lainnya. Keyakinan terhadap banyak Islam akan membuka peluang terhadap pluralisme dan keragaman sosial. ${ }^{56}$

TEOLOGIA, VOLUME 23, NOMOR 2, JULI-DESEMBER 2012 
Kemudian sejak tahun 2006, JIL meluncurkan penerbitan buletin yang memuat diskusi tentang isu-isu pluralisme dan kenegaraan modern bernama "Hiwar". Dalam perkembangan berikutnya, menurut keterangan Taufik Damas-salah seorang koordinator JIL-penerbitan buletin ini juga mengalami hambatan karena persoalan terbatasnya tim penulis. Walaupun demikian, tidak semua program JIL mengalami kemunduran, milis JIL misalnya, mendapatkan respon positif dari banyak pihak yang menghendaki agar diperluas menjadi website yang dapat diakses oleh banyak kalangan. Saat ini, semua produk JIL berupa sindikasi media, talkshow radio, artikel, dan perkembangan berita yang terkait dengan misi JIL di muat melalui website www.Islamlib.com. Sementara itu, milis tetap dipertahankan untuk kalangan terbatas saja. ${ }^{57}$

Dilihat dari grafik perkembangannya, memang tidak ada penambahan program atau bentuk sosialisasi ide-ide JIL yang signifikan. Hal demikian ini dibenarkan oleh Taufik Damas, yang menilai bahwa walaupun JIL mengajak untuk berfikir progresif, namun JIL menolak caracara revolutif untuk menyebarkan ide dan gagasan pemikirannya. Katanya,

Memang tidak ada perkembangan signifikan dalam bentuk program maupun sosialisasi ide-ide JIL selama sepuluh tahun belakangan ini. Benar JIL mengajak untuk berfikir progresif, tapi bukan berarti cara-cara yang digunakannya juga progresif. Misi sebenarnya dari JIL adalah mengajak orang untuk terbuka dan bebas berfikir. Nah, berfikir bebas dan terbuka itu tidak bisa dilakukan secara revolutif, tapi memang mesti lambat dan perlahan. Kami menolak cara-cara indoktrinatif seperti yang dilakukan kelompok-kelompok Islam fundamentalis seperti Ikhawul muslimun misalnya. Walaupun dalam beberapa hal cara-cara demikian itu memiliki kelebihan, tapi JIL menolaknya dan lebih memilih cara-cara dialog dan diskusi terbuka untuk menyebarkan ide-ide dan gagasannya. Bagi JIL, cara-cara indoktrinasi untuk berdakwah adalah "ahumanis", maksudnya mengabaikan aspek-aspek kemanusiaan yang seharusnya bebas untuk memilih informasi dari mana saja tanpa perlu diintimidasi dan ditakut-takuti dengan doktrin-doktrin agama yang ekslusif. JIL amat percaya dengan prinsip sunatullah, bahwa cara-cara yang sejalan dengan kebebasan fitri manusia itulah yang benar, dan karena itu pasti akan menang. ${ }^{58}$

Menurut Damas, sejauh ini JIL belum pernah melakukan evaluasi internal menyangkut sejauh mana program-programnya berhasil atau 
gagal. Bagi JIL, begitu Damas menjelaskan, program jangan dilihat sebagai sesuatu yang bersifat statistik. Betul bahwa jika ingin berhasil, organisasi apapun mesti memiliki tanzhim yang jelas minimal menerapkan prinsip 5W I H, atau SWOT. JIL juga menerapkan itu, tapi amat dibatasi dan sederhana sifatnya. Menurut Damas, biarlah lembaga lain yang melakukan riset atas capaian JIL menyebarkan ide-idenya, selanjutnya JIL akan menerima hasil riset itu sebagai pertimbangan langkah kedepan.

\section{E. Masa Depan Jaringan Islam Liberal di Indonesia}

Sebagai peng-counteride-ide fundamentalisme dan radikalisme di Indonesia, perjuangan JIL jadi tidak mudah. Dalam misinya mensosialisasikan ide Islam yang progresif-moderat, JIL setidaknya dibenturkan kepada dua kubu pemikiran di Indonesia, kaum tradisionalis-konservatif dan fundamentalis. Dari sudut pandang kaum tradisional, pemikiran JIL dinilai telah keluar dari kebiasaan-kebiasaan umat muslim (mazhab Syafi'i) yang telah dipahami secara berurat berakar selama ratusan tahun. Sedangkan dari sudut pandang kaum fundamentalis, pemikiran JIL dinilai telah keluar dari metode berfikir para salafus saleh dan pemahaman yang benar terhadap al-Quran dan Sunnah. Walaupun sama-sama mengkritik tradisi dan mengagendakan pembaruan, kaum fundamentalis menilai bahwa metode berpikir JIL sebagai tidak memiliki pijakan dalam ajaran Islam, tetapi mengekor kepada pemikiran sekular-liberal yang datang dari Barat.

Penolakan kaum tradisional konservatif, datang dari para kiai NU atau Muhammadiyyah yang anti pembaharuan. Mereka yang tidak menyukai dengan ide-ide JIL misalnya, menyelewengkannya dengan singkatan "Jaringan Iblis Laknatullah". Penolakan kaum tradisional konservatif juga datang dari lembaga fatwa ulama Indonesia (MUI) yang pada tahun 2005 mengeluarkan fatwa dan memberi label haram atas ideologi sekularisme, pluralisme dan liberalisme yang diusung JIL. Menurut Budhy Munawar Rachman, walaupun secara umum ditujukan kepada siapa saja yang menyetujui gagasan pluralisme, sekularisme dan liberalisme, sebenarnya fatwa pengharaman MUI tersebut ditujukan secara langsung kepada pikiran-pikiran yang diusung oleh JIL ini. ${ }^{59}$

TEOLOGIA, VOLUME 23, NOMOR 2, JULI-DESEMBER 2012 
Penolakan-penolakan yang datang kepada JIL bukan hanya dalam bentuk kritikan dan fatwa pengharaman ide, lebih dari itu, bahkan dalam bentuk fatwa mati. Kejadian ini bermula ketika Ulil Abshar Abdalla, salah seorang aktivis JIL, mempublikasikan sebuah artikelnya di kolom harian Kompas pada tanggal 18 November 2002 berjudul "Menyegarkan Kembali Pemahaman Islam" yang kemudian mendapat respon repressif dari kelompok Forum Ulama Umat Islam (FUUI) dari Bandung berupa fatwa mati terhadap Ulil. Dalam tulisannya, Ulil mengatakan bahwa prinsip-prinsip Islam berdasarkan al Quran dan sumber-sumber hukum Islam yang lain, seperti Hadist, Ijma' atau Ijtihad personal harus dilihat dari perspektif kontekstual sesuai dengan situasi sosial masa itu. Ulil juga mengatakan bahwa umat muslim saat ini tidak perlu mengikuti aturan-aturan yang bersifat lokal-kontekstual tersebut, dan mestinya memandang nabi Muhammad dalam perspektif seorang figur sejarah. Ulil tidak mengira statemennya yang sederhana itu berbuntut panjang dan harus melahirkan respon yang berlebihan dari kelompok tersebut. ${ }^{60}$ Menanggapi respon tersebut, Ulil dalam wawancaranya dengan majalah Syir'ah mengatakan,

Semula saya mengganggap biasa-biasa saja, tapi lama kelamaan saya khawatir juga. Saya juga marah, karena itu bagian dari arogansi keberagamaan, karena dia merasa paling suci, paling Islami sendirian. Ketika itu saya katakan kepada berbagai media, kalaupun ada yang merasa terhina, saya tidak menghina Islam, tapi menghina pemahamannya tentang Islam. Jadi kalau pak Athian (ketua FUUI) menganggap saya menghina Islam, berarti dia menyamakan pandangannya tentang Islam dengan Islam itu sendiri. Seolah-olah Islam itu hanya Islam yang dia pikirkan dan tidak ada dimensi-dimensi lain dalam Islam. ${ }^{61}$

Selain pandangan miring maupun fatwa-fatwa pengharaman, penyesatan, hingga fatwa mati, kritik dan hujatan terhadap JIL juga muncul dalam bentuk buku-buku maupun artikel, baik yang temanya secara langsung menunjuk organisasi ini, maupun yang menghujat pemikiran-pemikiran liberal secara umum. Sebut saja buku bertema "Bahaya Islam Liberal" yang ditulis oleh seorang jurnalis muslim Hartono Ahmad Jaiz adalah salah satu contohnya. Orang ini juga dikenal aktif menyerang ide-ide dan tokoh JIL maupun Islam liberal 
secara keseluruhan. Orang yang juga menulis buku berisi hujatan terhadap pemikir-pemikir liberal dari IAIN-" Ada Pemurtadan Di IAIN" - ini menyebut penjulukan pemikir liberal sebagai pembaharu atau kaum modernis sebagai suatu kerancuan yang berasal dari konspirasi Barat dengan sarjana Indonesia yang belajar di Barat, sekaligus merupakan suatu kriminalitas. Katanya "...pencetus penyelewengan yang seharusnya dihukum, malah diposisikan sebagai orang terhormat, yaitu dianggap mujaddid atau pembaharu. Ini justru sudah memutarbalikkan perkara, yaitu penyelewengan ajaran Islam didudukkan sebagai pejuang dan dan pemikir Islam. Inilah suatu kriminalitas yang sangat berbahaya..."

Buku lainnya yang berisi gugatan atas JIL dan pikirannya, misalnya terlihat dari dua tulisan Adian Husaini, salah seorang aktivis komite Indonesia Untuk Solidaritas Dunia Islam (KISDI) dan Dewan Dakwah Indonesia (DDI), yang dikenal aktif meng-counter dan memojokkon pikiran-pikiran dan tokoh-tokoh JIL dan Islam liberal secara umum. Dua tulisan yang dicetak hingga berulang-ulang kali itu masing-masing bertajuk " Islam Liberal: Sejarah, Konsepsi, Penyimpangan dan Jawabannya" dan " Wajah Peradaban Barat: Dari Hegemoni Kristen ke Dominasi Sekural Liberal". Jika buku yang pertama berisi hujatan kepada pemikir dan pikiran-pikiran liberal yang dinilai sebagai suatu bentuk penyimpangan ajaran (heresy), maka melalui buku yang keduanya tersebut, tokoh ini dengan pelbagai argumennya mencoba membuktikan penyimpangan seperti disebut di atas dengan cara menghubung-hubungkan tokoh dan pemikiran liberal di Indonesia dengan pemikiran Kristen Barat dan para Zionis.

Untuk melengkapi gambaran tentang penentangan terhadap pikiran progresif Islam liberal dan terutama JIL, sebuah buku bertajuk "50 tokoh Islam Liberal Di Indonesia" ditulis oleh seorang jurnalis muda lulusan IPB, Budi Hardianto, dapat dikemukakan di sini. Buku setebal tidak kurang dari 250 halaman ini hadir ditujukan sebagai "pencegahan awal" terhadap para tokoh liberal dan gagasan-gagasannya. Adian Husaini yang memberi pengantar untuk penerbitan ke lima buku ini mengatakan " ...saya melihat buku yang ditulis oleh saudara Budhi ini 
sebagai upaya praktis untuk membantu umat Islam Indonesia dalam melakukan deteksi dini terhadap paham-paham liberal di kalangan umat Islam melalui deteksi para pembawa paham ini..." ${ }^{13}$

Dengan pengakuannya sebagai gerakan peng-counter ide-ide fundamentalisme dan radikalisme Islam yang muncul pasca era orde baru, kelihatannya perkembangan JIL semenjak berdirinya pada tahun 2001 tidak terlalu signifikan. Melalui analisa kasar dan agak simplistis, dengan menggunakan tolak ukur kuantitas peredaran buku-buku, maka perbandingan jumlah peredaran buku-buku yang diterbitkan JIL atau bertema liberal kelihatan kurang berkembang jika dibandingkan dengan buku-buku rivalnya, baik yang mengkampanyekan ide-ide fundamentalisme dan radikalisme Islam maupun yang menyudutkan JIL dan Islam liberal. Perlu penelelitian lebih seksama dan serius, entah faktor apa yang menyebabkan buku-buku kategori kedua ini begitu laris dipasaran dan mengalami cetak ulang hingga berkali-kali.

Namun demikian, laporan penelitian Burhannuddin Muhtadi, seorang tokoh LSI tentang potret Islam pasca orde baru mungkin dapat memberi sedikit bayangan menjawab pertanyaan di atas. Melalui paper yang dipresentasikannya pada diskusi berkala di komunitas budaya Salihara Pasar Minggu-Jakarta, peneliti ini mencoba menggambarkan lewat penelitian kuantitatifnya bahwa kebangkitan keberagamaan di Indonesia paska rezim order baru bergerak ke arah yang makin mengkhawatirkan. Pasalnya, dalam paper itu dilaporkan bahwa bersamaan kebangkitan keberagamaan, sikap intoleransi dan anti demokrasi dalam masyarakat Indonesia menunjukkan grafik yang semakin menanjak. ${ }^{64}$ Hasil survey demikian ini tentunya berbeda dengan asumsi publik yang mengatakan bahwa selera masyarakat terhadap segala sesuatu yang berbau formal agama makin menipis, dengan fenomena menurunnya angka pemilih terhadap partai-partai Islam dan meningkatnya pemilih partai nasionalis misalnya.

Dalam studi gerakan sosial, ada dua tema penting terkait dengan penilaian maju atau mundurnya gerakan sosial tersebut. Pertama, latar belakang kemunculan gerakan tersebut, kedua, bagaimana gerakan sosial tersebut menyampaikan pesan ideologinya agar diterima 
masyarakat (metodologinya). Jika penolakan keras JIL terhadap ide indoktrinasi sebagai metode penyampaian ideologinya dihubungkan dengan teori klasik August Comte tentang perubahan sosial, maka alasan ini dapat diterima. Dalam hal ini, perubahan yang ingin dilakukan JIL melalui pembaruannya itu tergolong perubahan kultur. Terkait dengan ini, berarti perubahan kultur masyarakat dari anti demokrasi kepada demokrasi, dari intoleransi kepada pluralisme, dan dari otoritarianisme pemikiran kepada kebebasan berfikir, berpendapat dan egalitarianisme. Perubahan demikian ini tidak mungkin dilakukan secara revolutif, tetapi lebih secara evolutif. Jika kita merujuk kepada usaha nabi Muhammad mengubah kultur masyarakat badui menjadi masyarakat beradab misalnya, membutuhkan tempo hingga tidak kurang dari dua abad hingga ia mencapai puncak kemegahannya di masa pemerintahan Abbasiah. Begitu juga jika kita merujuk kepada pencerahan di Eropa misalnya, bahkan perlu tidak kurang dari empat abad dari mulai munculnya Averroisme latin pada abad ke-13 M hingga Eropa memetik hasilnya pada masa revolusi Eropa di abad ke-17 M.

Meskipun demikian, pernyataan di atas disampaikan bukan bermaksud sebagai legitimasi terhadap sikap JIL, yang menurut beberapa kalangan dinilai sebagai "elitis". Bagaimanapun juga, sebuah gerakan pemikiran dituntut untuk mampu mengukur diri sejauh mana ide-ide atau gagasannya telah berhasil diserap oleh masyarakat luas. Tujuannya agar ide atau gagasan tersebut tidak dianggap sebatas gerakan wacana belaka (al-harakah al-auräqiyyah), tetapi lebih serius sebagai gerakan perubahan (al-harakah al-taghyiriyyah). Terkait dengan ini, sebetulnya JIL mengakui bahwa kelahirannya juga merupakan upaya untuk menghapus kesan "elitisme" itu pada sejumlah pemikirpemikir liberal sebelumnya yang terbatas hanya bergerak pada wilayah akademis atas (top-acadeic), dan tidak menyentuh lapisan bawah, ${ }^{65}$

Walaupun kesan elitis itu sulit dihilangkan dari gerakan JIL, tapi sejatinya gerakan pemikiran progresif ini mengaku bercita-cita agar ide dan gagasannya ini bisa diserap hingga kalangan "mushalla". Terkait dengan ini, Ulil Abhsar Abdalla, tokoh kenamaan JIL memberi komentar,

TEOLOGIA, VOLUME 23, NOMOR 2, JULI-DESEMBER 2012 
Kita ingin gagasan Islam Liberal sampai level mushalla. Tentu ada halhal yang sulit dibicarakan kepada umat, tapi saya punya bayangan pemahaman minimal ala Islam liberal itu ada. Misalnya, meredefinisikan kembali apa itu iman dan Islam. Menurut saya, pendekatan rasional bisa kita pakai pada seluruh aspek dalam keberagamaan mulai dari cara memahamai iman. Saya berfikir dalam jangka panjang kita perlu membuat suatu risalah tentang reorientasi shalat, karena itu basis ibadah yang paling penting dalam Islam. Reorientasi shalat dari segi hikmah dan tujuannya. ${ }^{66}$

Abdalla juga mengakui, benar bahwa Masjid merupakan sarana penting dalam setiap gerakan Islam dan basis penyebaran gagasangagasannya. Namun demikian, Islam liberal tidak bisa berharap banyak pada Masjid yang selama ini didominasi dan dijadikan transmisi gagasan keagamaan yang kalau tidak radikal, minimal konservatif. Karena itu, ia mencita-citakan untuk memiliki lembaga pendidikan sendiri yang independen dari SD hingga tingkat universitas untuk menjadi basis penyebaran gagasan Islam liberal.. ${ }^{67}$

Memang agak sulit memahami ritme gerak JIL, terutama jika dikatakan bahwa JIL tidak berhasrat menjadi ormas Islam baru yang masif, seperti NU dan Muhammadiah, dan lebih memilih menjadi "pedagang ide yang kecil" tapi lincah. ${ }^{68}$ Padahal pada kesempatan lain, Abdalla juga mengandaikan adanya kondisi kultur masyarakat yang terdidik sebagai wadah penyemaian dan diseminasi gagasan-gagasan sekularisme, pluralisme dan liberalisme sebagai bentuk ide yang dipahami dengan pendekatan yang rasional dan kontekstual. ${ }^{69}$ Kepasifan JIL juga terlihat dalam konteks menanggapi klise-klise negatif dari lawannya. Memang kasus demikian ini dalam beberapa hal diakui amat mengganggu karena banyak orang yang termakan isu tersebut, tapi bagi JIL, begitu Abdalla menjelaskan, tidak akan menanggapi secara repressif fitnah tersebut dan lebih memiliki bergerak sesuai dengan ritmenya sendiri. ${ }^{70}$ Menurut Taufik Damas, JIL lebih bangga ketika orang-orang yang mendukung dan datang ke JIL karena faktor natural dan hubungan intelektual yang lumrah, ketimbang masa banyak tapi merupakan hasil indoktrinasi dan rekayasa i-natural. ${ }^{71}$

Menurut Abdalla, walaupun lambat, tapi bukan berarti JIL dengan kesan "elitisme" nya itu gagal sama sekali. Selama sepuluh tahun ini, 
minimal kehadiran JIL dapat menjadi gerakan yang mampu membangun arus kesadaran keberagamaan baru di Indonesia. Kehadiran sosok keberagamaan baru, begitu Abdalla, mampu menjadi pengimbang terhadap pola keberagamaan lain yang sifatnya radikal. Memang diakui, JIL belum punya cukup kaki untuk menyebarkan ide. Sarana diseminasi ide kebanyakan masih bersifat virtual, dan itu tidak cukup, perlu mempunyai jaringan yang lebih baik di bawah kalangan mahasiswa dan masyarakat. Menurut Abdalla, kesulitan terbesar kaum intelektual adalah harus berada pada dua tuntutan yang sulit didamaikan. Di satu sisi, mereka harus memasarkan ide dan membuat ide yang rumit menjadi mudah dipahami, tapi di sisi yang lain mereka dituntut untuk memperbarui ide-idenya. Bagi Abdalla, keberhasilan JIL ditingkat elit untuk sementara ini dirasa sudah cukup, karena menggaet khalayak umum bagi JIL adalah cita-cita jangka panjang, dan bukan untuk sekarang-sekarang ini. ${ }^{72}$

Menurut hemat penulis, meskipun diserang bertubi-tubi oleh banyak kelompok, dan begitu besar harga yang mesti dibayar demi mensosialisasikan ide-ide pembaruannya, JIL patut bersyukur lahir dalam kondisi di mana situasi politik memungkinkan dan mendukung. Dengan begitu, JIL memiliki umur yang panjang hingga mencapai satu dasawarsa sekarang ini. Keadaannya mungkin jadi berbeda jikalau kondisi politik di Indonesia dikuasai oleh kelompok keagamaan tertentu yang bersebrangan dengan gagasan JIL misalnya. Seandainya kondisi politik demikian ini dapat ditingkatkan, atau minimal dipertahankan, walaupun berjalan lambat, kemungkinan besar JIL memiliki masa depan yang panjang di Indonesia. Berbeda misalnya, jika dibandingkan dengan nasib seperti dialami oleh tokoh-tokoh pembaru di tengah yang mesti mengalami eksegesi dari tanah airnya.

Terakhir, selain faktor kaderisasi tentu saja, orientasi gerakan Islam liberal di masa depan juga kelihatannya perlu ditinjau ulang. Jika orientasinya hanya sebatas meng-counter ide-ide radikal dan fundamentalis Islam di Indonesia, maka pertanyaan dari banyak kalangan tentang kelanjutan eksistensi Islam liberal jika kaum fundamentalis telah bubar layak direnungkan kembali. ${ }^{73}$ Mengutip analisa pemikir muda progresif Zuhairi Misrawi "Islam liberal harus mempertimbangkan kembali stra-

TEOLOGIA, VOLUME 23, NOMOR 2, JULI-DESEMBER 2012 
tegi dakwahnya di masa mendatang, tentu saja dengan tidak menafikan gagasan fundamentalis sebagai salah satu sasarannya. Islam liberal harus mulai merambah problem-problem kekinian, memihak dan menyentuh masyarakat paling bawah, sehingga kehadirannya memberikan makna yang riil bagi masyarakat akar rumput. Pilihan-pilihan moral yang harus diutamakan adalah keadilan, kesejhteraan, kedamaian dan keadaban. Islam liberal harus menjadi Islam progresif, caranya, jangan hanya bermain dalam isu abstrak, melainkan dapat merambah gagasan yang bersifat praksis. ${ }^{174}[]$

\section{Catatan Akhir}

${ }^{1}$ Jhon L. Esposito, Islam The Straight Path, New York: Oxford University Press, 2005, h. 228.

${ }^{2}$ Ibid.

${ }^{3}$ Ibid, h. 229.

${ }^{4}$ Ibid.

${ }^{5}$ Ibid, h. 231.

${ }^{6}$ Ibid.

${ }^{7}$ Kelompok neomodernis kebanyakan adalah para pembaharu yang berlatar belakang tradisi. Kebanyakan dari mereka, kemudian melanjutkan studi di negeri-negeri Barat dan mengkolaborasikan pemahaman tradisional mereka dengan teori-teori sains modern. Sebut saja tokoh-tokoh seperti Ali Shari'ati dan Abdul Karim Sorroush dari Iran merupakan alumnus masing-masing dari Universitas Sorbonne dan Universitas London. Dari Tunisia ada Rachid Ghanousi dan dari Sudan ada Hasan Turabi. Dari Malaysia ada Anwar Ibrahim; juga Nurcholis Madjid, Amien Rais dari Indonesia. Kemudian dari Mesir ada tokoh Hasan Hanafi pengusung gagasan Islam kiri. Lih.: Jhon L. Esposito, Islam, h. 232.

${ }^{8}$ Lih.: Greg Barton, The Emergence of Neo-Modernism: A Progressive, Liberal Movement of Islamic Thought In Indonesia, terj. Nanang Tahqiq, Jakarta: Paramadina, 1999, h. 4.

${ }^{9}$ Lih.: Muhammad Ali, The Rise of Liberal Islam Network (JIL) in Contemporary Indonesia, di muat dalam The American Journal of Islamic Social Sciences 22: 1, h. 3 .

${ }^{10}$ Lih.: Majalah Gatra, Perlawanan Islam Liberal, edisi 1 Desember 2001, h. 29.

${ }^{11}$ Ali Said Damanik, Fenomena Partai Keadilan: Transformasi 20 Tahun Gerakan Tarbiyyah di Indonesia, Jakarta: Teraju, 2002, h. 215.

${ }^{12}$ Lih.: Zachary Abuza, Militant Islam in Southeast Asia: Crucible of Teror, Collorado: Lynne Rienner Publisher Inc, 2003, h. 69. 
${ }^{13}$ Lihat Muhammad Ali, The Rise of Liberal Islam Network.

${ }^{14}$ Terkait dengan ini, ada sebuah laporan penelitian menarik yang disusun oleh The Wahid Institute yang berkerjasama dengan yayasan TIFA. Laporan ini mencatat tentang perkembangan regulasi keagamaan di Indonesia dan kasus-kasus anti pluralisme di Indonesia. Dalam kesimpulan akhir penelitian tersebut, dijelaskan bahwa akhir-akhir ini, fenomena kebangkitan agama di Indonesia tampil dengan wajah yang kurang menyenangkan. Pernyataan ini terutama ditunjukkan oleh meningkatnya intoleransi, dan kekerasan atas nama agama, mulai dari yang berbentuk penyesatan hingga kekerasan fisik. Di akhir laporan penelitian tersebut dicantumkan grafik dan tabel tentang kekerasan dan intoleransi di Indonesia yang menunjukkan fenomena yang makin meningkat. Lih.: The Wahid Institute, The Wahid Institute Annual Report 2008 on Religious and Belief Pluralism in Indonesia, Jakarta: The Wahid Institute and TIFA, 2008.

${ }^{15}$ Ibid.

${ }^{16}$ Luthfi Assaukani, Islam and The Secular State In Indonesia, Singapore: Institute of Southeast Asian Studies, 2009, h. 201.

${ }^{17}$ Budhy Munawar Rachman, Reorientasi Pembaharuan Islam: Sekularisme, Liberalisme dan Pluralisme Paradigma Baru Islam Indonesia, Jakarta: Paramadina, 2010, h. 33.

${ }^{18}$ Lih.: Ulil Abshar Abdalla, Menjadi Muslim Liberal, Jakarta; Jaringan Islam Liberal, 2005, h. 5.

${ }^{19}$ Budhy Munawar Rachman, Reorientasi Pembaharuan, h. 183.

${ }^{20}$ Ibid, h. 188.

${ }^{21}$ Model pertama, negara demokrasi Islam (IDS: Islamic Democratic State), diusulkan oleh M. Nastir di awal-awal berdirinya Republik Indonesia. Argumen Natsir adalah Islam itu lengkap (shāmil) dan sempurna (kämi). Islam tidak boleh digantikan dengan ideologi apa pun, termasuk dalam hal bernegara. Model kedua, negara demokrasi agama (RDS: Religious Democratic State), model ini didasarkan atas fakta bahwa Indonesia adalah negara plural. Model ini dijalankan dalam era pemerintahan Soeharto. Model ketiga, negara demokrasi liberal (LDS: Liberal Democratic State). Model ini merupakan usulan untuk mendiskusikan persoalan politik di luar ranah keagamaan. Tokoh di Indonesia yang mengusulkan ide negara ini menurut Luthfi adalah mantan Presiden Abdurrahman Wahid (alm), dan pemikir kenamaan Nurcholis Madjid. Lih.: Luthfi Assaukanie, Islam and The Secular State, h. 12-18.

${ }^{22}$ Ibid, h. 151.

${ }^{23}$ Budhy Munawar Rachman, Reorientasi Pembaharuan, h. 193-195.

${ }^{24}$ Zakiyuddin Baidhawy, Ber-Islam di Era Multikulturlisme, dalam Abd. Moqshit Ghazali [ed.], Ijtihad Islam Liberal: Upaya Merumuskan Keberagamaan yang Dinamis, Jakarta: Jaringan Islam Liberal, 2005, h. 49.

TEOLOGIA, VOLUME 23, NOMOR 2, JULI-DESEMBER 2012 
${ }^{25}$ Jalaluddin Rakhmat, Islam dan Pluralisme: Akhlak Qur'an Menyingkapi Perbedaan, Jakarta: Serambi Ilmu Semesta, 2006, h. 20.

${ }^{26}$ Budhy Munawar Rachman, Reorientasi Pembaharuan, h. 631.

${ }^{27}$ Ibid, h. 539-540.

${ }^{28}$ Ibid, h. 565.

${ }^{29}$ Ibid, h. 567.

${ }^{30} \mathrm{Ibid}$, h. 382-386.

${ }^{31}$ Ibid, h. 331.

32 Ibid, h. 357. Lihat juga Djohan Effendi, Harus Ada Kebebasan Tidak Beragama, dalam Luthfi Assaukanie [ed.], Wajah Islam Liberal di Indonesia, Jakarta: Jaringan Islam Liberal, 2002, h.136.

${ }^{33}$ Budhy Munawar Rachman, Reorientasi Pembaharuan, h. 363.

${ }^{34}$ Ibid, h. 359.

${ }^{35}$ Ibid, h. 370.

${ }^{36}$ Ibid, h. 350.

37 Ibid, h. 396. Lihat Juga Muhammad Iqbal, Reconstruction of Religious Thought in Islam, terjemahan Arab oleh 'Abbas Mahmud, Damaskus: Dār al-Haitsam, 2000, h. 147.

${ }^{38}$ Budhy Munawar Rachman, Reorientasi Pembaharuan, h. 431.

${ }^{39}$ Ibid, h. 383.

${ }^{40}$ Sinta Nuriyah Wahid, "Islam Memihak Perempuan," dalam Abd Moqsith Ghazali [ed.], Ijtihad Islam Liberal, h. 253. Mengenai wacana gender dan pembaruan hukum keluarga Islam dan isu-isu feminisme dalam pandangan muslim progresifmoderat, seputar kasus poligami, talak, nikah dan waris, diuraikan dalam Nashirudin dan Sidik Hasan, Poros-Poros Ilahiyyah: Perempuan Dalam Lipatan Pemikiran Muslim Liberal Versus Tradisional, Surabaya: Jaring Pena, 2009, h. 46; juga Syafiq Hasyim, Bebas Dari Patriarkhisme Islam, Jakarta: Kata Kita, 2010, h. 107-108.

${ }^{41}$ Menurut Syafiq Hasyim, salah seorang pemikir Muslim progresif yang aktif menulis tentang isu-isu gender, belakangan ini ada perkembangan baru dalam pandangan kaum muslim terhadap perempuan, terutama di Indonesia. Perkembangan itu terutama ditunjukkan dalam produk undang-undang dan munculnya gerakangerakan civil society yang pro gender. Hasyim menyebut ada tiga perkembangan. Pertama, lahirnya UU PKDRT yang berhasil mempublikkan hak-hak perempuan yang tadinya terisoslasi. Dengan adanya UU ini, kata Hasyim, hak-hak perempuan yang selama ini dianggap sebagai privat, menjadi dihargai eksistensinya di ruang publik. Kedua, gerakan anti poligami, kemajuan ini ditunjukkan oleh maraknya gerakan protes publik yang dilakukan jamaah perempuan terhadap pemuka-pemuka agama yang melakukan praktek poligami. Ketiga, gender mainstreaming. Perkembangan ini, 
menurut Hasyim ditunjukkan terutama oleh munculnya instruksi presiden no. 9 tahun 2000 tentang pengarusutamaan gender. Lih.: Syafiq Hasyim, Bebas Dari Patriarkhisme Islam, h. 132-136.

${ }^{42}$ Nasaruddin Umar, Hijabisasi Perempuan Dalam Ruang Publik, dalam Luthfi Assaukanie, Wajah Islam Liberal, h. 47.

${ }^{43}$ Nurcholis Madjid, et. al., Fiqih Lintas Agama: Membangun Masyarakat Inklusif-Pluralis, Jakarta: Paramadina, 2004, h. 254; juga Abd. Moqsith Ghazali, Argumentasi Pluralisme Agama: Membangun Toleransi Berbasis al Quran, Jakarta: Kata Kita, 2009, h. 326.

${ }^{44}$ Nasirudin dan Sidik Hasan, Poros-Poros Ilahiyyah, h. 252.

${ }^{45}$ Lih.: Nong Darol Mahmada, "Kritik Atas Jilbab", dalam Abd. Moqsith Ghazali, Ijtihad Islam Liberal, h. 129; juga Saiful Amin Solihin, Menyorot Aurat dan Jilbab, h. 135; Musdah Mulia, Tidak Boleh Ada Pemaksaan Jilbab, dalam Luthfi Assaukanie [ed.], Wajah Islam Liberal, h. 129.

${ }^{46}$ Lihat Husein Muhammad dan Nur Rofi'ah, "Perempuan Boleh Mengimami Laki-Laki", dalam Abd. Moqsith Ghazali, Ijtihad Islam Liberal, h. 279; Luthfi Assaukanie, Islam Benar Versus Islam Salah, Jakarta: Kata Kita, 2007, h. 31.

${ }^{47}$ Program Jaringan Islam Liberal, diakses dari www.Islamlib.com pada tanggal 20 Januari 2010.
${ }^{48}$ Ibid.
${ }^{49}$ Ibid.
${ }^{50}$ Ibid.
${ }^{51}$ Ibid.
${ }^{52}$ Ibid.
${ }^{53}$ Ibid.
${ }^{54}$ Wawancara dengan Taufik Damas, on February $2^{\text {nd }} 2011$. Sciences, Ohio University, unpublished, h. 101.

\footnotetext{
${ }^{56}$ Luthfi Assaukanie, Islam Benar, h. 96.

${ }^{57}$ Wawancara dengan Taufik Damas, 2 Februari 2011.

${ }^{58}$ Ibid..
}

55 Iklan layanan masyarakat ini sempat tayang selama dua pekan sebelum kemudian pada tanggal 4 agustus 2002 kelompok ekstrimis muslim dari Majlis Mujahidin Indonesia (MMI) mendatangi dua stasiun televisi swasta yang menayang kannya. Kedatangan kelompok ekstrimis tersebut dilakukan untuk mengancam akan melakukan tindakan perlawanan bagi siapa saja yang menayangkan iklan tentang ajaran Islam yang salah, tidak sesuai dengan Qur'an dan Sunnah. Lihat Nicolaus Teguh Budi Harjanto, Islam and Liberalism in Contemporary Indonesia: The Political Ideas of Jaringan Islam Liberal (JIL), Thesis Submitted to the Faculty of the College of Arts and 
${ }^{59}$ Lihat Budhy Munawar, Reorientasi Pembaharuan., h. 29.

${ }^{60}$ Lihat Nicolaus Teguh Budi Harjanto, Islam and Liberalism, h. 102-103.

${ }^{61}$ Majalah Syir'ah, Edisi April 2005.

${ }^{62}$ Lih.: Hartono Ahmad Jaiz, Bahaya Islam Liberal, Jakarta: Pustaka Kautsar, 2002, h. 28.

${ }^{63}$ Adian Husaini, Dari Yahudi Liberal ke Islam Liberal, dalam Budi Hardianto, 50 Tokoh Islam Liberal di Indonesia, Jakarta: Hujjah Press, 2008, h. xxxix.

${ }^{64}$ Lebih detail mengenai hasil survey LSI ini silahkan merujuk Burhanuddin Muhtadi, Demokrasi Zonder Toleransi: Potret Islam Pasca Orde Baru, Paper dipresentasi-kan dalam diskusi "Agama dan Sekularisme di Ruang Publik" komunitas Budaya Salihara, pada Rabu, 26 Januari, 2011, Tidak diterbitkan.

${ }^{65}$ Lih.: Virginia M. Hooker, Developing Islamic Argument For Change Through Liberal Islam, dalam Amin Saikal dan Virginia M. Hooker [ed.], Islamic Perspective on The New Millenium: Iseas Series on Islam, Singapore: Institute of Southeast Asian Studies, 2004, h. 6.

${ }^{66}$ Ulil Abshar Abdalla, "Kita Ingin Islam Liberal Sampai ke Mushalla", Majalah Syri'ah, edisi April 2005.

${ }^{67}$ Ibid.

${ }^{68}$ Ibid.

${ }^{69}$ Wawancara dengan Ulil Abshar Abdalla, 29 Oktober 2010.

${ }^{70}$ Ibid.

${ }^{71}$ Wawancara dengan Taufik Damas, 2 Februari 2011.

${ }^{72}$ Ulil Abshar Abdalla, Kita Ingin Islam Liberal Sampai ke Mushalla, Majalah Syri'ah, edisi April 2005.

${ }^{73}$ Zuhairi Misrawi, "Dari Islam Liberal ke Islam Progresif," Pengantar dalam edisi terjemahan Membumikan Islam Progresif, lihat Shalahuddin Jursi, al- Islām alTaqaddumiyyūn, terj. Ainul Abid Shah, Jakarta: Paramadina, 2004, h. xii.

${ }^{74}$ Ibid, h. xiii.

\section{DAFTAR PUSTAKA}
Abdalla, Ulil Abshar, "Kita Ingin Islam Liberal Sampai ke Mushalla," Majalah Syir'ah, edisi April 2005.


Abdalla, Ulil Abshar, Menjadi Muslim Liberal, Jakarta; Jaringan Islam Liberal, 2005.

Abuza, Zachary, Militant Islam in Southeast Asia: Crucible of Teror, Collorado: Lynne Rienner Publisher Inc, 2003.

Ali, Muhammad "The Rise of Liberal Islam Network (JIL) in Contemporary Indonesia," The American Journal of Islamic Social Sciences 22: 1.

Assaukani, Luthfi, Islam and The Secular State In Indonesia, Singapore: Institute of Southeast Asian Studies, 2009.

Assaukani, Luthfi, Islam Benar Versus Islam Salah, Jakarta: Kata Kita, 2007.

Assaukani, Luthfi, Wajah Islam Liberal di Indonesia, Jakarta: Jaringan Islam Liberal, 2002.

Baidhawy, Zakiyuddin, "Ber-Islam di Era Multikulturlisme," dalam Abd. Moqshit Ghazali [ed.]., Ijtihad Islam Liberal: Upaya Merumuskan Keberagamaan yang Dinamis, Jakarta: Jaringan Islam Liberal, 2005.

Barton, Greg, The Emergence of Neo-Modernism: A Progressive, Liberal Movement of Islamic Thought In Indonesia, terj. Indonesia oleh Nanang Tahqiq, Jakarta: Paramadina, 1999.

Damanik, Ali Said, Fenomena Partai Keadilan: Transformasi 20 Tahun Gerakan Tarbiyyah di Indonesia, Jakarta: Teraju, 2002.

Effendi, Djohan, "Harus Ada Kebebasan Tidak Beragama", dalam Luthfi Assaukani, Luthfi, Islam Benar Versus Islam Salah, Jakarta: Kata Kita, 2007.

Esposito, John L., Islam The Straight Path, Newyork: Oxford University Press, 2005.

Ghazali, Abd. Moqsith, Argumentasi Pluralisme Agama: Membangun Toleransi Berbasis al Qur'an, Jakarta: Kata Kita, 2009.

Harjanto, Nicolaus Teguh Budi, Islam and Liberalism in Contemporary Indonesia: The Political Ideas of Jaringan Islam Liberal (JIL), Thesis Submitted to the Faculty of the College of Arts and Sciences, Ohio University.

Hasyim Syafiq, Bebas Dari Patriarkhisme Islam, Jakarta: Kata Kita, 2010.

TEOLOGIA, VOLUME 23, NOMOR 2, JULI-DESEMBER 2012 
Hooker, Virginia M., "Developing Islamic Argument For Change Through Liberal Islam," dalam Amin Saikal dan Virginia M. Hooker, Islamic Perspektive on The New Millenium: Iseas Serius on Islam, Singapore: Institute of Southeast Asian Studies, 2004..

Husaini, Adian, "Dari Yahudi Liberal ke Islam Liberal," pengantar dalam Budi Hardianto, 50 Tokoh Islam Liberal di Indonesia, Jakarta: Hujjah Press, 2008.

Iqbal, Muhammad, Recontruction of Religious Thougt in Islam, terjemahan Arab oleh 'Abbas Mahmud, Damaskus: Dar al Haitham, 2000.

Majalah Gatra, Perlawanan Islam Liberal, Edisi 1 Desember 2001.

Madjid, Nurcholish, et. al., Fiqih Lintas Agama: Membangun Masyarakat Inklusif-Pluralis, Jakarta: Paramadina, 2004.

Mahmada, Nong Darol "Kritik Atas Jilbab", dalam Abd. Moqsith Ghazali, Argumentasi Pluralisme Agama:Jakarta: Jil, 2005.

Misrawi, Zuhairi, "Dari Islam Liberal ke Islam Progresif," Pengantar dalam Shalahuddin Jursi, Membumikan Islam Progresif, terj. Ainul Abid Shah, Jakarta: Paramadina, 2004.

Muhammad, Husein dan Nur Rofi'ah, "Perempuan Boleh Mengimami Laki-Laki," dalam Abd. Moqsith Ghazali, Argumentasi Pluralisme Agama: Jakarta: JIL, 2005.

Nashirudin dan Sidik Hasan, Poros-Poros Ilahiyyah: Perempuan Dalam Lipatan Pemikiran Muslim Liberal Versus Tradisional, Surabaya: Jaring Pena, 2009.

Rachman, Budhy Munawar, Reorientasi Pembaharuan Islam: Sekularisme, Liberalisme dan Pluralisme Paradigma Baru Islam Indonesia, Jakarta: Paramadina, 2010.

Rakhmat, Jalaluddin, Islam dan Pluralisme: Akhlak Qur'an Menyingkapi Perbedaan, Jakarta: Serambi Ilmu Semesta, 2006.

The Wahid Institute, The Wahid Institute Annual Report 2008 on Religious and Belief Pluralism in Indonesia, Jakarta: The Wahid Institute and TIFA, 2008.

Umar, Nasarudin, "Hijabisasi Perempuan Dalam Ruang Publik," dalam Luthfi Assaukanie, Wajah Islam Liberal Indonesia, Jakarta: JIL, 2002.

Wahid, Sinta Nuriyah, "Islam Memihak Perempuan," dalam Abd Moqsith Ghazali, ed., Ijtihad Islam Liberal, Jakarta, JIL, 2005. 